\title{
A la junta de los ríos. Tensiones identitarias en Sur de Diana Bellessi y Perrimontun de Maribel Mora Curriao
}

\section{A la junta de los ríos. Identitary Tensions in Sur by Diana Bellessi and Perrimontun by Maribel Mora Curriao}

Karem Pinto Carvacho

Facultad de Filosofía y Humanidades, Universidad de Chile. Santiago, Chile karempinto.car@gmail.com

\section{Resumen}

El trabajo que se presenta a continuación expone una mirada conjunta sobre los textos poéticos Sur de Diana Bellessi y Perrimontun de Maribel Mora Curriao. El análisis se centra en la perspectiva sobre la diversidad étnica y de género, a las que ambas obras aluden. Así, por un lado, se refieren a la múltiple conformación mestiza de nuestro continente, alimentada por la presencia indígena y acrecentada por los diversos procesos migratorios, internos y externos; y, por otro, apuntan a la situación de las mujeres tanto al interior de las comunidades indígenas como en la posterior formación de los estados nacionales y su desarrollo, en un examen extendido hasta nuestro propio acontecer.

Palabras clave: poesía, mujeres, América Latina, identidad étnica y de género.

\section{Abstract}

This paper exposes an analysis of the poetics texts Sur by Diana Bellessi and Perrimontun by Maribel Mora Curriao. The article develops a perspective on the ethnic and gender diversity to which both texts allude. On the one hand, they refer the multiple mixed conformation of our continent, fueled by indigenous presence and increased by different migration processes, internal and external. On the other, these works point out to the situation of women both within indigenous communities and in the development of national states, in a review extended up to our days.

Keywords: Poetry, Women, Latin America, Ethnic and Gender Identity. 
Paso entre ellas y mis mejillas se manchan de tierra mojada.

G. Mistral, "Raíces"

Las huellas de los muertos están aquí.

L. Kiepja, en Los onas: vida y muerte

\section{Introducción ${ }^{1}$}

Sur de Diana Bellessi (Zabala, 1952) y Perrimontun de Maribel Mora Curriao (Panguipulli, 1970) parecen dos textos poéticos lejanos si pensamos en distancias evidentes, como lo son sus diversos contextos de producción, las particularidades de cada una de sus voces y las formas en que sus autoras se encargan de sus propios materiales poéticos, elaborados a partir de la búsqueda de sus ascendencias, en parte, también divergentes. Sin embargo, sus diferencias se aproximan en un espacio de reunión fundamental: ambos textos pueden ser considerados como viajes introspectivos, dirigidos a profundizar sobre el mismo campo de reflexión, es decir, las tensiones de la identidad étnica y sexo-genérica que dan forma a América Latina.

Así, mientras Diana Bellessi, de familia italiana, escribió Sur desde 1998 hasta 2003, año de su publicación, Maribel Mora Curriao, de raíces mapuche, publicó Perrimontun en el año $2011^{2}$. No obstante, ambas autoras, desde una mirada crítica sobre la exclusión étnica y genérico-sexual, despliegan sus elaboraciones poéticas refiriéndose, por una parte, a la múltiple conformación mestiza de nuestro continente, alimentada por la presencia indígena y acrecentada por los diversos procesos migratorios, internos y externos; y, por otra, aludiendo a la situación de las mujeres y la experiencia femenina, tanto al interior de las comunidades indígenas como en la posterior formación de los estados nacionales y su desarrollo, en un examen provisto por un trabajo de memoria que ellas extienden desde un acontecer que las interpela.

En estos sentidos, podríamos decir que ambas obras están definidas por un agudo cuestionamiento a la concepción de la nación o a lo que Benedict Anderson denominó las comunidades imaginadas, pues, tal como piensa Mary Louise Pratt, esa perspectiva presenta una versión idealizada, en que las homologías lengua-nación y cultura-nación son construidas y comprendidas como prácticas horizontales, sin ser representativas de una realidad total y diversa. En opinión de Pratt, la categoría de lo nacional no es capaz de incorporar el conjunto al que hace alusión, ya que las agrupaciones sociales

1 El presente artículo se enmarca dentro del proyecto REDES CONICYT 130057, del cual es Investigadora Responsable la Dra. Alicia Salomone.

2 Para este análisis, trabajo con la versión del poemario que la poeta me facilitara personalmente en el año 2009. Le agradezco profundamente el compartir conmigo los primeros textos que dieron vida a su trabajo poético final. 
"que habitan los territorios nacionales están cargadas de heterogeneidad y jerarquías que actúan en contra de la fraternidad, la autonomía y la soberanía" (52). Esta figura moderna, agrega: "Está interminablemente expuesta a ataques, desafíos, contrahegemonías y formaciones alternativas que la obligan a afirmarse y a reafirmarse a través de la negociación y la fuerza" (52). Así, concluye que las naciones se han constituido ficcionalmente en los imaginarios de la homogeneidad, marginando o encubriendo la diferencia como un mecanismo más en la detentación del poder.

En coherencia con la posición de Pratt, tanto Sur como Perrimontun, apartados de ese tipo de imaginario nacional, excluyente para las mujeres y los diversos grupos étnicos que componen las naciones, optan por una visión formulada desde categorías más porosas y plurales. Lo que llevan a cabo desplegando un singular y potente sentido de memoria que busca reconstruir genealogías comprometidas con la reposición de los pasados históricos, familiares y personales que han sido relegados a los relatos privados. Una reconstrucción elaborada a partir de una posición consciente respecto de los contextos enunciativos problemáticos que cada autora habita, donde ambas ven cómo el pasado obstruido interrumpe permanentemente sus existencias.

Así, para Bellessi, el contexto de producción de Sur se halla marcado por los conflictos generados a partir de una desconcertante posdictadura y los trágicos efectos del doble período menemista en Argentina (1989-1999), en el que se aplicaron las leyes de Punto Final y Obediencia Debida en el terreno político, así como un fuerte plan de privatizaciones en el plano económico, lo que condujo a la severa crisis que azotó al país entre 1999 y 2002. Por su parte, para Mora Curriao, el lugar de enunciación refiere la incesante violencia tanto física como simbólica y judicial ejercida en contra del pueblo mapuche bajo los gobiernos de la Concertación, que han generado una serie de dispositivos represivos desconociendo su situación histórica. De esta manera, ambos textos poéticos presentan un plan de escritura común, en que pasado y presente se entrelazan avivando la memoria social y particular, comunitaria e íntima, expresada como una labor en la que se asume el encuentro y el compromiso con los de antes. A través de ellos, sus autoras han acudido a "la secreta cita entre las generaciones", con la que Walter Benjamin (40) aludía al deber de todo sujeto reflexivo frente a la exigencia del pasado, sosteniendo así un ejercicio de memoria entendido como un acto redentor de las comunidades oprimidas.

En esta dirección, se acercan las reflexiones que Julia Kristeva ha registrado en torno a los alcances de lo que denomina cultura de la "re-vuelta" y que entiende como un proyecto político dispuesto a la obtención de la autonomía, en el que la memoria juega un papel fundamental. Kristeva insiste sobre la trascendencia de los procesos de interrogación y restablecimiento del pasado que pueden sostener tanto el psicoanálisis como la literatura, porque ambos campos implican y pueden hacerse cargo de un ejercicio de retorno-inversión-desplazamiento-cambio. Un proceso que, según su propia visión, hoy por hoy tiene mayor sentido que la vigilancia del futuro inmediato, ya que para su construcción este dependería de un acto reflexivo sobre los sucesos anteriores. 
Esta alerta sobre la necesidad de "indagación" de lo pretérito concuerda perfectamente con el desarrollo de los proyectos poéticos que nos convocan, puesto que ambos intentan, con palabras de Kristeva, "reiniciar sin tregua el retorno retrospectivo que lo[s] conduce a las fronteras de lo representable-pensable-sostenible, hasta la 'posesión"' (14). Dicho de otra forma, mediante la posibilidad de examinar al propio ser, de buscarse a sí mismas, las hablantes de estos textos líricos se posicionan en una aptitud para el "retorno" que "es a un tiempo rememoración, interrogación y pensamiento" (13), provocando con ello la apertura de contenidos excluidos u obliterados, críticos o problemáticos; es esto lo que permitiría su rehabilitación para la construcción identitaria tanto personal como cultural o colectiva. De este modo, el sentido de heterogeneidad que reclamaba Pratt a la conformación del imaginario nacional resulta cubierto por las apreciaciones de Kristeva, pues ella sostiene que es imposible entender esta búsqueda de la apropiación del ser, esta regresión reflexiva, como un asunto estable y armónico. Ambas posturas se enlazan cuando la autora francesa afirma: "La permanencia de la contradicción, la provisionalidad de la reconciliación, la puesta en evidencia de todo aquello que pone a prueba la posibilidad del sentido unitario, como la pulsión, lo femenino innombrable, la destructividad, la psicosis, etcétera, es lo que explora esta cultura-re-vuelta" (20).

Siguiendo a Kristeva, podríamos puntualizar: la crisis de la identidad compacta, el desajuste del sentido homogéneo de lo nacional, la constitución genérico-sexual abierta a la pluralidad y la mixtura de las ascendencias; tales son algunos de los sentidos "revoltosos" que estos poemas ponen en marcha. Esas señas se encuentran inmediatamente expuestas, por ejemplo, en los gestos de apertura textual, como lo son el título de "hija perdida" (extraviada, desviada, descentrada) que se da la escritora argentina en la dedicatoria de Sur -dirigida a manifestar su deuda poética con "los dichos y cantos de los Pueblos Americanos" ${ }^{3}$. Asimismo, también aparecen en el establecimiento de la ascendencia que dispone el principio mapuche con que se inicia Perrimontun, que, inscrito en mapudungun, dice: "IÑEY NO RUME KIMLAY CHEU AMUTUAL KIMNOLU CHEU ÑI, ÑI KUPALME”, cuya traducción en la misma página señala: "Nadie puede saber dónde ir, si no sabe de dónde viene" (1).

Lo que ambos textos poéticos proponen desde sus inicios es la exploración de la configuración étnica de nuestro continente para establecer con ella un vínculo directo, y al hacerlo entienden la complejidad de los procesos que allí se dan cabida, pero además la abordan desde un enfoque que contempla la diferencia de la experiencia femenina. Este viaje a las "Raíces" -como dijera Gabriela Mistral en el Poema de Chile (672)- implicará la instalación re-vuelta de diversidades desbordantes, en las cuales ambas voces poéticas se reconocerán como mujeres y mestizas, es decir, como

3 Luego de dirigirse directamente a tres representantes de las comunidades indígenas americanas (Lola Kiepja, Agustina Kilchamal y Ailton Krenax), agrega: "Doy gracias a sus almas que se dejan oír, que sueñan y siembran en la oreja impropia de la hija perdida" (5). 
sujetos provistos de una experiencia doblemente problemática y excluyente ${ }^{4}$. Mistral ya se había referido a la complejidad del proceso identitario femenino latinoamericano, observando ambos espacios y estableciendo las tensiones de estas diferencias incardinadas. En este sentido, el poema mencionado alude a la profundidad de un pacto identitario doble, tanto con la experiencia de las mujeres como con su identificación indígena (Baeza, Rojo). Allí la escritora chilena, en su descenso a través de la tierra, nos dice:

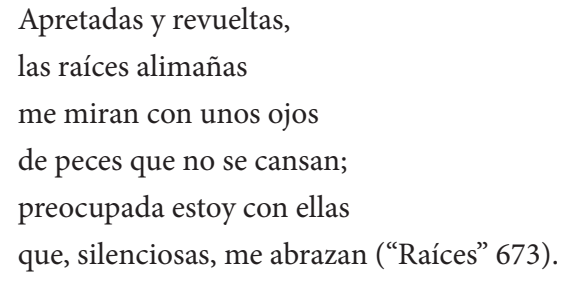

Así como el Poema de Chile, Sur y Perrimontun aluden a la diversidad de los trayectos que configuran el continente latinoamericano. Se trata de la representación poética de experiencias que resultan representativas de los procesos sociales por los cuales transitan las diferencias, y que se señalan como rutas cruzadas por sentidos de rupturas, apropiaciones, reformulaciones y conquistas identitarias. En consecuencia, nos enfrentamos a textos en que la subversión de las jerarquías y la exploración de las identidades subalternas y plurales ponen en cuestión el pensamiento establecido y provocan la desestabilización de los códigos sobre los que se constituye el orden presente. Son textos que, mediante la potencia de la palabra poética, irrumpen y desarticulan el monólogo incesante de los discursos del poder.

\section{Doble instalación escritural: subjetividades indígenas y de mujeres}

Los viajes poéticos encaminados al pasado que proponen Sur y Perrimontun devienen en el posicionamiento de las diversas realidades indígenas a las que aluden, y que se complejizan al contemplar el lugar sexo-genérico desde el cual ambas obras son producidas. De esta manera, observaremos que en sus desarrollos líricos las perspectivas étnica y genérico-sexual son expuestas en conjunto, aunando los costos de la exclusión que ello implica -el no lugar, como señala Sur en su epígrafe-, pero proponiendo formas de superación de ese estado marginal. Con esa seña a la diferencia y a la singularidad,

4 Así se refiere Cornejo Polar a la colisión problemática y asimétrica de dos o más culturas anteriores, como una de las partes del proceso cultural al que me refiero: "Varias veces he comentado que el concepto de mestizaje, pese a sus tradiciones y prestigio, es el que falsifica de manera más drástica la condición de nuestra cultura y literatura. En efecto, lo que hace es ofrecer imágenes armónicas de lo que obviamente es desgajado y beligerante, proponiendo figuraciones que en el fondo sólo son pertinentes para quienes conviene imaginar nuestras sociedades como tersos y nada conflictivos espacios de convivencia" (6). 
el mundo poético será impulsado a través del vigor chamánico de sus hablantes a través de dos mecanismos: en Sur, la petición y la invocación -“¡lanza relámpagos colibrí!”, "Oh Kiepja no me dejes/ sentar en hain equivocado" (7-8)-; y, en Perrimontún, el establecimiento de las normas ancestrales -"El silencio sostiene el linaje y la muerte/ único refugio el camino y la palabra” (2)-. A partir de allí, ambos textos se poblarán de diversas imágenes de mujeres que dan vida a la escena poética, convertida en una especie de ritual catártico que busca dar luz sobre olvidos y negaciones.

En relación a ello, podemos percibir que el entramado poético que compone Sur se afirma sobre una tríada femenina, compuesta por una voz de mujer, a la que se acercan la imagen de Lola Kiepja, la última sel'knam que conservó las costumbres de su etnia hasta su propia muerte en 1966, y la imperceptible figura de Anne Chapman, antropóloga francesa autora de El fin de un mundo: Los selk'nam de Tierra del Fuego (1989), quien a partir de 1964 mantuvo largas entrevistas y un cercano contacto con la mujer indígena. Bellessi plasma tal encuentro étnico, sexo-génerico y espiritual en esta vinculación tripartita que contempla la figura de la mujer indígena y la de la europea ubicadas como actantes poéticas centrales. Su relación es inmediata ya en el epígrafe y el agradecimiento, desde donde se extiende a toda la obra mediante la réplica de una serie de triángulos de similar constitución cuya vibración amplifica sus sentidos.

En efecto, ciertos momentos que Chapman vivió junto a Lola, y que ella relata en su propio texto, aparecen recreados poéticamente en Sur. Por tanto, la voz de Sur se aproxima suavemente a la de la científica, mediante la representación lírica de esos recuerdos. Es lo que sucede, por ejemplo, con el relato de las largas caminatas que Champan y Lola emprendían a pedido de la mujer selk'nam, porque, tal como le confesara a la europea, no quería olvidar su costumbre de habitar Tierra del Fuego. Asimismo, ocurre con la recreación de los cantos ceremoniales del hain que Kiepja recordaba y que explicó, cantó y danzó para Champan ${ }^{5}$. El relato de la antropóloga retrata así dichos momentos:

Con frecuencia me proponía ir a ciertos lugares distantes a muchos kilómetros. Estaba convencida de poder caminar mucho más de lo que realmente podía. Pero casi diariamente salíamos cerca para recoger leña y a veces caminábamos a unos pocos kilómetros de su casa, ella apoyándose en su bastón, para visitar lugares donde había vivido o sitios de campamentos de paisanos muertos (28).

Y agrega: "Lo que realmente disfrutaba eran los cantos. Cuando cantaba los del hain se acompañaba haciendo pantomima de los pasos de baile y gestos del espíritu en cuestión" (28). El eco de esas vivencias y su sentido resuenan a cada paso en Sur. De modo que, cuando la poesía se hace cargo de aquellos encuentros, paseos y cantos,

5 En un artículo anterior realicé un análisis de Sur en torno a sus dos sentidos centrales: el colibrí y el hain selk’nam. Ver Pinto, Karem. "Nombrar el margen: etnia y género en Sur de Diana Bellesi". Caminos y desvíos. Lecturas críticas sobre género y escritura en América Latina. Eds. Alicia Salomone, Lorena Amaro y Ángela Pérez. Santiago de Chile: Cuarto Propio, 2010. 
entonces la voz lírica parece tomar el lugar de la investigadora en esa misma escena; y, más allá de aquella, al interrumpir toda lógica temporal, mediante la palabra poética y el profundo poder de la memoria, mágica y concentradamente, la hablante traslada al presente los escenarios ancestrales del mismo hain y de la vida selk'nam en la Patagonia: de la caza de ballenas para alimentar a la comunidad, de las caminatas por la Tierra del Fuego, de los cantos que animaban los rituales, de la vida cotidiana, de la preparación de los cuerpos adornados y pintados para el hain. "Avivo el fuego" (38), dice la poeta, y nos lleva con ella, como quien persiste en poner en movimiento esta memoria a través de la poesía. La imagen poética que trae, y nos transporta a, ese mundo se despliega de la siguiente forma en el poema DESPUNTA EL ROBLE, el que cito en extenso por la belleza de la escena y para dejar expuesta la correspondencia con el relato de Chapman:

$$
\begin{aligned}
& \text { Estoy oyendo a Kiepja } \\
& \text { última de su pueblo } \\
& \text { con una toca de plumas } \\
& \text { la cara en arcilla roja? } \\
& \text { Público de los dioses } \\
& \text { ahora es la que canta } \\
& \text { la que guarda "para los indios } \\
& \text { del norte". Para mí } \\
& \text { en trance frente al fuego? }
\end{aligned}
$$

Escala las laderas

de la montaña en seda,

senda abierta por otra

mujer. Aguilucho

mi wáiwun desde allí

sana. Avivo el fuego

$(\ldots)$

Tres días tres noches

cantamos para sostener

vivas a las ballenas

En el helado mar

antártico hilos

invisibles entretejen

nuestro wáiuwen. Comer

Curar. Cántame:

ala ala mientras

bajamos a la ladera (38). 
El trozo poético se despliega sobre diversas antítesis suavemente reunidas en una larga estructura sinestésica que implica a la vez la escucha de voces y cantos, la visión de luces matinales y la oscuridad nocturna que marcan el paso del tiempo, la sensación del gélido clima patagónico y el calor de la fogata de la memoria avivada. Todo lo cual da vida a una escena que el texto narrativo de Chapman no logra recrear, quizás porque los objetivos poéticos son diferentes a la informativos, que con llaneza buscan exponer el fin de una etnia. De modo que, mientras Chapman refiere las dificultades de las caminatas y los deseos frustrados de una mujer anciana, Bellessi realiza una operación distinta: la de dar impulso a la imagen de la mujer indígena, porque solo a partir de ella, junto con la fuerza que puede obtener del ritual y la palabra indígena ("wáiwun"/ fuerza), podrá resarcir la fisura mortal que pesa sobre y separa a las comunidades. La sinestesia, entonces, le permite desatar los sentidos que se mueven sanos y naturales, dando frescura y potencia a una escena de vida plagada de seres ("Kiepja", "dioses", "indios del norte", la hablante, un "Aguilucho", "ballenas"), desenvuelta en un ambiente nativo ("laderas", “montañas", el "mar", el frío austral y "el fuego") que fluye vigoroso al compás del tiempo, la actividad diaria y los cantos de las mujeres. Allí, es la hablante quien se muestra dubitativa de su entrada al espacio ("la cara roja en arcilla?"; "en trance frente al fuego?"), ante una mujer segura que canta y se desliza por los senderos ("Escala las laderas / de la montaña en seda"), sujeto portadora de una voz clara, que firmemente interrumpe en la textualidad del poema para señalar la dirección de su discurso ("para los indios / del norte") y que amorosa entona canciones dedicadas a la calma de los niños ("ala ala").

En el recorrido de este texto, la escritura poética permite un lazo existencial continuo que hace estallar las voces femeninas que intervienen en su construcción: la voz que canta, la que oye y registra y la voz que poetiza. Es una dicción que no distingue tonos entre la que "guarda para los indios del norte", la que recoge material de estudio y la que reconstruye la presencia de los pueblos ancestrales mediante la poesía. Las tres voces "avivando el fuego", las tres voces involucradas en un acto de retrospección y meditación, las tres sanando los lugares de la historia que han sido dañados y obstruidos... las tres mirándose, escuchándose y reconociéndose: las tres reconstruyendo los mapas de la memoria.

Así, pienso que el viaje americano que delinea Sur puede ser comprendido desde su inicio como el trayecto que la voz poética emprende junto a estas dos mujeres inscritas en el texto, viaje que acaba en un encuentro que no distingue voces, figuras ni vivencias, pues aquellas optan por fundirse dialogando, cantando, pensando y sintiendo. Esos cruzamientos iluminan la experiencia femenina para culminar con el fin del "secreto" del hain, consistente, según la interpretación de la misma Chapman, en el mito fundacional patriarcal alimentado por los hombres sel'knam para mantener la sumisión de sus mujeres (54); una lectura que Bellessi apoya, consintiendo una vez más en los múltiples encuentros entre el texto científico y el poético. Así lo dice la hablante: 


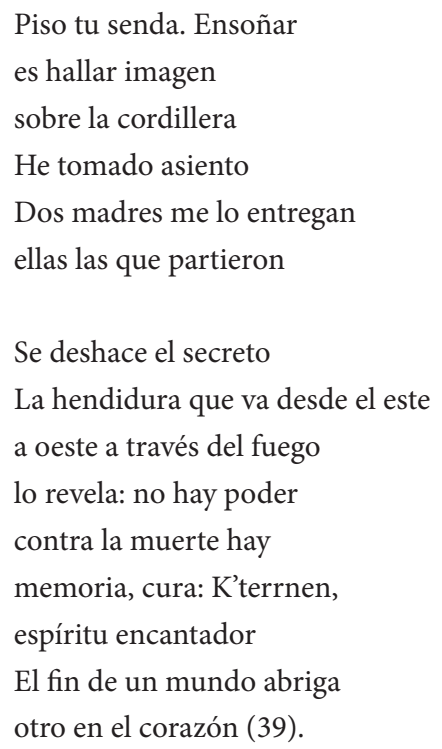

En consecuencia, la búsqueda del pasado indígena de la comunidad contemporánea que establece la hablante de Sur, si bien revela la perpetuación del orden social que niega la existencia de una comunidad paritaria, también permite superar esa imposibilidad en el mismo poema mediante la fusión de la tríada femenina y su instalación al centro del ritual selk’nam, lugar prohibido a sus mujeres ("He tomado asiento/ Dos madres me lo entregan”). De allí proviene el cambio: el nacimiento de una nueva forma de comprensión, simbolizada en K'terrnen, el hijo de Xalpen, el "bebé resplandeciente" del hain. En tal dirección, el llamado contra la muerte inevitable resulta ser la memoria, que se deja ver como el destello emitido por la presencia del nuevo hijo selk'nam, como réplica del fulgor que trajo consigo la aparición del colibrí al inicio del texto poético -"Lanza relámpagos, colibrí!” (7)-. Así, en el reconocimiento de sus presentes vinculados al pasado, ambas imágenes poéticas resplandecen; ambas se articulan recuperadas del peligro de ser sometidas a los terrenos cenagosos del olvido y el silencio, de ser reducidas a manos del triunfo discursivo del relato hegemónico.

Por su parte, en Perrimontun, apreciaremos una situación similar respecto de la reconstrucción de la memoria familiar y ancestral, pero con determinadas particularidades. En el texto poético de Mora Curriao, la presencia indígena se manifiesta emplazando su lugar étnico enunciativo, primero a través del título de la obra y luego a través del epígrafe correspondiente a un principio de la sabiduría mapuche ancestral, como vimos ("IÑEY NO RUME KIMLAY...”). De esta forma, la enunciante nos advierte explícitamente que irá en busca de sus raíces. Esa intención es reafirmada en el primer poema del texto, titulado "Kupalme" (2), que repite el fundamento identitario del principio mapuche antes mencionado, potenciando de esa forma el 
objetivo textual, pues dicho vocablo (kupalme) indica la norma dictada por el mundo natural (o ñuke mapu), correspondiente al deber de conocer al lonko que dio origen al linaje del cual se proviene ${ }^{6}$.

De modo que, así como Sur refiere un viaje indagatorio por el continente americano, Perrimontun también refiere un "desplazamiento" territorial, pero esta vez denotando las marcas de la "expulsión" de las tierras de origen. Este trayecto, en el cual ciertos autores han visto un correlato bíblico del éxodo judío, será revisado por la voz poética desde la identificación de un linaje en el que las figuras femeninas (la madre: "Elsa madre de los pewmas de mi origen", y la abuela: "Manuela amor ciego y abundante") destacan por sobre las masculinas (José Manuel y José Ignacio ${ }^{7}$ ). Así, en el poema de apertura ("Kupalme") que, como vimos, pedía el descubrimiento del lonko fundador, la voz poética distinguirá a esas mujeres en primer lugar, agregando a esa intención la presencia de la bisabuela ("Margarita kurru ou tú la madre la abuela / Ferviente y tenaz en tu huida, / pueblos todavía sin cruces") como iniciadora de la migración familiar forzada. En ese sentido, Pedro Gissi señala la existencia de tres generaciones que dan forma a la presencia urbana mapuche, las que en el caso de esta obra son representadas por sus mujeres. Por tanto, podríamos entender que los versos señalados apuntan a la construcción de una genealogía femenina en que la bisabuela adquiere un rol protagónico, pues con ella se inicia la estirpe desplazada que culminará en el clan urbano constituido por la/el abuela/o, la madre y la hablante ${ }^{8}$.

El cambio de lonko por fundadora, a mi juicio, no implica una transgresión de género dirigida a arreglar cuentas con la cultura mapuche ${ }^{9}$. De hecho, no parece haber en este texto poético una problematización de los lugares de género al interior de la cultura indígena, porque además su objetivo apunta a revitalizar su posición, estableciendo y reconstruyendo la historia de resistencia y dolor que ha implicado el desplazamiento del pueblo mapuche, sostenida, vuelvo a repetir, en la figura de sus mujeres. A mi modo de ver -y entendiendo que el contexto de la producción poética

6 En adelante, todas las menciones al pensamiento mapuche, el significado de sus rituales, símbolos o definiciones serán tomadas de forma general de los textos de Juan Pablo Manquenahuel, a no ser que se cite otra fuente.

7 Luego los nombres de Manuel, Ignacio, Santos, Manuel, Edgardo e Ignacio se homogeneízan en el nombre de José.

8 Según Gissi, la primera generación (1930-1950) correspondería a un conjunto de inmigrantes individuales -mayoritariamente hombres- que, con ansias de regreso a su modo de vida rural, optan por invisibilizarse a sí mismos y a los suyos y terminan asimilándose a la cultura ambiental urbana, limitando su identidad como mapuche (en el conocimiento de su lengua, básicamente) al espacio privado del hogar. La segunda generación (1950-1980), a diferencia de la anterior, ya no se forma culturalmente en el conjunto de la comunidad mapuche. Por lo tanto, "enmascarando" su identidad étnica, y en condiciones sociopolíticas adversas para la expresión de cualquier tipo de particularidad, se esfuerza por integrarse al mundo laboral de la metrópoli, aunque sigue manteniendo contacto con las comunidades del sur. Por último, la tercera generación (1980 hasta nuestros días), los actuales jóvenes, son nietos de los primeros migrantes y se encuentran en un proceso de replanteamiento de su identidad mapuche. En este conjunto, el "caso Ralco" en el Alto Bío Bío, desde 1999, y los conflictos con hacendados y empresas forestales por la propiedad de las tierras en la Araucanía figuran como hitos que han significado, en gran parte del pueblo mapuche, una revaloración y reacercamiento a su identidad cultural (9).

9 Aunque en la historia oficial la mayoría de los lonko son figuras masculinas y aún queda por investigar la presencia femenina, Sonia Montecino expresa que no puede verse la cultura mapuche de manera idéntica a la occidental respecto de la repartición de roles genéricos, ya que podemos reconocer lugares de importancia de la mujer en la machi, por ejemplo. 
de Perrimontun es urbano y contemporáneo, y que además se establece una mirada crítica sobre él-, podemos deducir que la finalidad de esta reposición de la genealogía femenina mapuche radicaría en demostrar la poca presencia que tienen las mujeres mapuche en la historia oficial chilena y universal, evaluando la mirada androcéntrica del lugar desde el cual la hablante enuncia su discurso. En este sentido, el poema dedicado a la figura de Berta Quintremán, líder pehuenche que a partir de la década de 1990 dio una prolongada lucha contra el proyecto de la central hidroeléctrica Ralco, entre otros poemas, orienta la lectura propuesta a través de una imagen antitética de las posiciones culturales enunciadas. Allí la hablante forma parte de un colectivo ("nosotros") expuesto como lugar que es reprobado, frente a la figura de la mujer que simboliza el espacio de la resistencia cultural. El poema se dirige a ella:

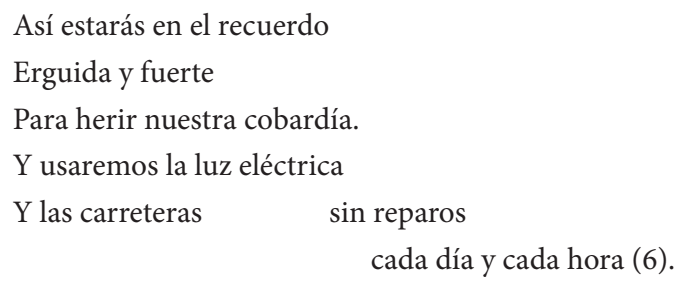

Esta intención de empoderamiento sexo-genérico y étnico-cultural es reiterada en la numerosa cantidad de imágenes de mujeres que acompañan a la voz poética y que dirigen la primera parte del texto. Una especie de "locas mujeres mistralianas" que reafirman la legitimación de la locura o trascordura como forma de relación y conocimiento de signo femenino, que transgrede la normativa del sistema sexogénero mediante sus arranques, fortaleza y desenfado, para contestar a los brutales desalojos de todo tipo soportados por la comunidad mapuche. A diferencia de Sur ${ }^{10}$, la composición plural de Perrimontun va a establecer una identificación directa de la hablante con la cultura mapuche, en la que es imposible eludir la referencia grupal del lof, forma básica de organización social radicada en el clan familiar o linaje. Entre esas figuras se encuentra la misma enunciante, en el poema titulado "Aquí estoy hermanos" -"Levanto la cabeza del polvo / de las generaciones / Recojo mis huesos" (4)-; y junto a ella "La Bartola", figura histórica que intervino enérgicamente en la ocupación de Truf truf - “¡Detengan a la Bartola / ¡Deténganla que no se cansa!” (5)-; Berta Quintremán, antes mencionada -"erguida y fuerte", "aferrada al pie del árbol" (6)-; y, luego, su madre - "Nada nos detiene / en tus brazos no caemos" (7)- y su bisabuela en "Canción a Margarita Curriao", poema que vuelve, como sucede en "Kupalme", sobre el leitmotiv del relato poético: las múltiples desterritorializaciones

10 La reunión de mujeres que establece Perrimontun presenta cierta distancia respecto de la tríada que sostiene la red textual de Sur (conformada, recordemos, por la hablante, Lola y Chapman), más cercana en tal caso al pensamiento occidental en cuanto a su estructura, pues se trata de una réplica de la Sagrada Familia o la familia edípica, aunque intervenida en el poema de Bellessi por la presencia de estas tres mujeres. 
mapuche abiertas al destino aciago -"Por todo el nag mapu hermanos, caminaremos" (14)-. Así, "la partida de las tierras del Pehúen" (11) por los diversos caminos emprendidos hacia la urbe ("sangres dispersas", "tu linaje perdido", "estamos lejos ahora", "en este valle perdido", etc.) es el tema central del texto poético, proceso del cual la hablante resulta ser trágicamente heredera ${ }^{11}$. Señala el texto:

$$
\begin{aligned}
& \begin{array}{l}
\text { Margarita Curriao viene } \\
\text { caminando cuesta abajo } \\
\text { con sus sueños, con sus miedos }
\end{array} \\
& {[\ldots]} \\
& \text { Los hijos vivos que quedan } \\
& \text { de a poco se van marchando. } \\
& \text { Por mujer y por trabajo } \\
& \text { La ciudad los va llamando. } \\
& \text { Margarita ya no canta, } \\
& \text { sus temores va guardando. } \\
& \text { En este valle perdido } \\
& \text { tendrá su postrer descanso. } \\
& \text { En silencio sueña nieve } \\
& \text { quebradas, ríos y pájaros (9). }
\end{aligned}
$$

El poema construye su relato en base a tres elementos: un trayecto y dos actantes que se comportan como fuerzas antagónicas, la sujeto poética y la muerte. Formalmente, está compuesto por tres estrofas, cada una de las cuales marca los tres espacios o momentos en los que se divide el viaje y la diversa manera en que los personajes interactúan. En la primera estrofa, que corresponde al inicio de la ruta, la sujeto identifica a su contendor, la muerte, simbolizada por el canto de un "urco”, y lo rechaza: (“ ¿Espanten de aquí ese pájaro!”, “Mala señal ese canto!”); en la segunda estrofa, en la continuación del camino, la muerte, personaje silencioso, "se va asomando" y apropiando de los suyos ("una cruz y un condenado / le recuerdan sus temores", "Se ha llevado a la Clorinda / y a la niña con su manto"); y en la estrofa final, la sujeto es consumida por la fuerza opositora ("Ya no hay luz en tu mirada / la montaña está llamando"), con lo cual queda establecido el infortunio sobre la estirpe venidera.

11 Ese largo camino de desterritorialización se acrecienta al contemplar otras formas de reducción e incorporación del pueblo mapuche a la sociedad chilena, que podemos entender como un proceso de invisibilización largo, pero continuo, habilitado a través de la educación formal, las misiones religiosas y, posteriormente, el servicio militar. Esta ocupación física y cultural provocó el decrecimiento de los espacios de producción y reproducción que, junto con la reconversión económica de la Ix región (del trigo a la industria ganadera y luego a la forestal), ha concluido en una manifiesta situación de indigencia y marginación (Gissi 6; Jones 12). 
Hasta allí las posiciones de las dos poetas parecen bastante claras: por una parte, la afirmación del mundo indígena constitutivo de la identidad latinoamericana desde su origen, exiliado y olvidado, pero presente en nosotros mismos; y por otra, la perspectiva de género sobre ese mundo, que implica la develación de las diversas historias de mujeres silenciadas por el discurso público occidental. Sin embargo, el interés en el desocultamiento de esas experiencias busca la alimentación y comprensión de la situación presente de las hablantes, como dijimos en un principio, enunciando ambas desde una situación de urbanidad globalizada, problemática y desconcertante. En este sentido, cada hablante asumirá las diferentes transferencias de su situación intercultural, intentando resoluciones también diversas frente a la propia conformación mestiza.

\section{Culturas en tensión, posicionamiento cultural}

La identificación de la voz poética de Sur con la mujer sel'knam presenta un claro énfasis ("Vuelvo al llamado de los pueblos / a lo arcaico que hay en mí", dirá la voz poética en su recorrido). Como vimos anteriormente, este encuentro étnico, sexogénerico y espiritual también comparte lugar y representación con la voz de Chapman, en una dirección que deja entrever la aceptación del lugar entre culturas. Esa posición quedará demostrada en otros poemas que repiten la misma fórmula tripartita femenina ya mencionada. Así se expresa, por ejemplo, en el poema "Cazador de Sueños":

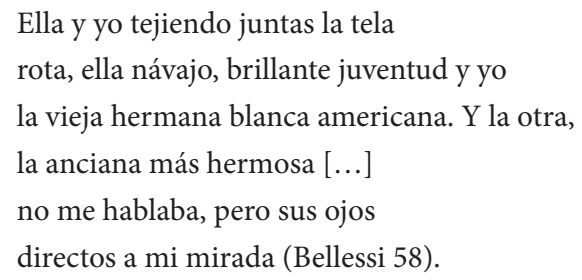

El poema está constituido hasta aquí por la presencia de tres mujeres: la indígena návajo, la hablante y la anciana. Allí la autodenominación de "vieja hermana blanca" no pasa desapercibida, pero tampoco el vínculo intenso y directo con la madre ancestral, de quien debe sostener su mirada fuerte y vigilante: todas reconstruyendo la "tela rota", metáfora de la barbarie sobre los relatos históricos y culturales marginados. En esa misma dirección podríamos poner a circular los versos en los que la hablante de otros poemas hace mención a su ascendencia italiana, y con ella a la inmigración europea que a finales del siglo xIx y principios del xx transformó la fisonomía de la Argentina hasta el día de hoy ("Anunciación de la primavera" 87). De esa manera, se deja aparecer la vivencia infantil en la recreación de un refrán, formato textual coloquial que mezcla poesía y sabiduría, enunciado en voz europea - "rosa-soy niña otra vez- / di sera, buon tempo si spera” (87)-. Imagen experimentada, recordada o recreada, en y desde América, en alusión a la búsqueda y la esperanza inmigrante 
de mejores días en las tierras americanas. Este poema revela así, mediante forma y contenido, la condición desfavorecida de la filiación europea que la obra expone.

Esa memoria sobre una historia de sobrevivencia, pobreza, desamparo, pero también de ilusión y fortaleza familiar se hará evidente, más tarde, en el valor del alimento y los dichos de la nonna respecto de su carencia -"no pongas al revés el pan / sobre la mesa" (109)-. Las imágenes van destrabando la memoria y son repuestas en la misma lengua italiana - ¿Lucciola? / Ya viene el trigo” (109)-, estableciendo una identificación directa con los desposeídos de la tierra. Esta vez el poema reveladoramente se titula "Despierto en ella", como si la memoria familiar trajera conciencia de pertenencia y sentido de vida. La presencia de la "madonna Annunziata” “ ¿Es la Primavera...?” 88) subraya ese suceso, pero su transfiguración en la imagen de Ometeótl, -Señor/a, divinidad azteca, representante de la dualidad- tejedora "de los mantos del Ande" (88), marcará la reposición del pensamiento indígena y la aceptación del proceso transcultural común al enfrentamiento de los imaginarios que han dado origen a la identidad de la hablante poética.

Con todo, esta doble identificación, lejos de ser armoniosa, se presenta como problemática para la hablante, quien reconoce en sí misma la tensión y dificultad de su constitución cultural. Tal constitución está marcada por un pensamiento occidental identificado con el carácter masculino que, a pesar de ser rechazado, le impide acceder a una parte de su identidad étnica, que se identifica con la indígena americana. La imagen metonímica referida a los fragmentos, a partir de los cuales debe reconstruir esa identidad, señala la dificultad del proceso. Así lo señala el poema "LO PROPIO Y LO AJENO": "Reclama herencia / la hija para / vivir y encuentra / pedazos escandidos / en la nada (...) / Es mi trampa y es mi casa" (22). Sin embargo, mediante la comprensión de su constitución identitaria heterogénea, expresada mediante la antítesis que la define ("trampa"/ "casa"), la hablante de Sur logra traspasar los límites de un pensamiento cristalizado, y así optar por la aceptación crítica de lo ajeno y asumir la comprensión de la identidad como un constructo social y dinámico: “( ...) aceptar/ lo otro si lo otro / no te arrasa // si condición de su / existencia no supone / tu exterminio / sino, cambio / en movilidad perpetua" (23).

La hablante resuelve este conflicto optando por una perspectiva integrada o plural, la que a vista de Gloria Anzaldúa (2005) correspondería a una forma particular de la expresión de lo que llama la "conciencia mestiza". Según su visión y experiencia personal -la misma Anzaldúa se define como chicana y lesbiana-, la conciencia de la mestiza se caracteriza por un pensamiento divergente, "por un movimiento que se aleja de normas y objetivos establecidos, hacia a una perspectiva más amplia, que incluye en lugar de excluir" (707), y que manifiesta tolerancia a las contradicciones y ambigüedades. Su identidad, continúa, no puede concebirse como una puesta en equilibrio de las culturas o una red armónica como expresión de ellas, sino más bien como la manifestación de ellas en un tercer elemento, proveniente de un choque intenso de poderes que comprende confusión y dolor, y que se identifica con un "con- 
tinuo movimiento creativo que sigue quebrando el aspecto unitario de cada nuevo paradigma" (707). La mujer mestiza, explica:

Aprende a ser india en la cultura mexicana, a ser mexicana desde el punto de vista angloamericano. Aprende a equilibrar las culturas. Tiene una personalidad plural, actúa de modo pluralístico, nada es dejado de lado, lo bueno, lo malo, lo bello, lo feo. No sólo mantiene contradicciones, también transforma la ambigüedad en otra cosa (algo así como que transforma la ambivalencia, la invierte o resuelve de otro modo) (707).

Por su parte, la situación de la hablante de Perrimontun no parece diferente, pues el carácter intercultural de su enunciación también nos hablará de una sujeto atravesada por dos culturas en tensión, la que en su caso posicionará a la identidad mapuche, marginada pero en proceso de reconfiguración. En ese sentido, un poema fundamental es "Sueños en el valle" que, enunciado en primera persona singular femenina, identifica y señala el complejo lugar físico y cultural desde donde declara su discurso:

Heme aquí, apartada de mis muertos

perdida en el Valle del Águila,

olvidada del pehuén y la montaña.

En sueños he visto

que brota sangre de mi costado

y nacen aves rapaces de mis sienes

que devoran mis manos y mi lengua (Mora 16).

El poema descubre la figura de una sujeto urbana trastocada, alejada de su cultura de origen, quien a través de sus sueños (pewmas) -recurso fundamental del conocimiento para el pensamiento mapuche- recibe una autoimagen de muerte que puede ligarse a la imagen del profeta judío crucificado y herido en un "costado", representación de un imaginario cristiano occidental. Esa alusión a la introducción de un pensamiento foráneo queda reafirmada en la imagen siguiente, la que refiere el choque de voces culturales que la desestabilizan, simbolizadas en la figura de "aves rapaces" nacidas de sus "sienes" (rapaz/ rapax, "inclinado a, enviciado en el hurto, robo, rapiña" ${ }^{12}$ ); una usurpación que se extiende sobre su "lengua" y sus "manos", símbolos de la expresión, la actividad y la creación cultural. En consecuencia, la apariencia de su estado actual, referido a través de trozos de su cuerpo, es la de la enfermedad, el dolor y la descomposición, provocados por la violenta imposición de una cultura extranjera. Continúa el poema:

12 Continúa la definición del diccionario de la RAE: "Robo, expoliación o saqueo que se ejecuta arrebatando con violencia" (1288) 


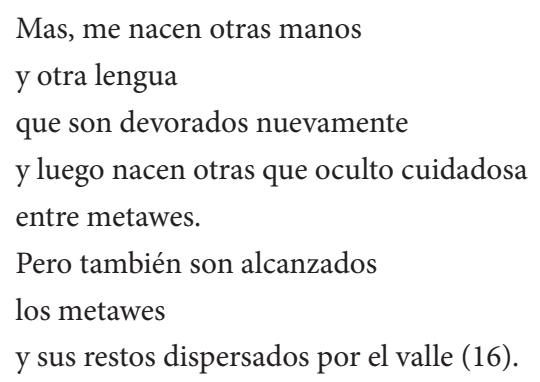

El proceso de des/re/articulación se vuelve circular. Existe un deseo y una fuerza de resistencia constante, sometida al orden de diversas fuerzas, entendidas como nuevas condiciones culturales. Así, finalmente, alude a su posición mapuche al buscar, con atención y conciencia, la protección de su identidad entre metawes, cántaros que simbolizan la salvación. Pero su aniquilación persiste y la imagen gira en torno a los "restos" esparcidos, símbolo de la fragmentación física y cultural. Así como los integrantes de su comunidad, que luego de la seguidilla de migraciones al sur y norte del país han sido diseminados por doquier; así como el saber mapuche, sumido en la violencia simbólica permanente: fragmentos diseminados, "pedazos escandidos en la nada" (22), dice uno de los poemas de Sur, reiterando las imágenes del quiebre.

Si prestamos atención a "Sueños en el valle" de Perrimontun, observaremos que las referencias al mito griego de Prometeo encadenado son fáciles de apreciar: devorada por aves rapaces, la hablante muere en el Valle del águila, y así como Prometeo veía crecer nuevamente sus entrañas, lo mismo le sucede a ella con sus manos y su lengua. Sin embargo, en los versos subsiguientes, el mito es apropiado y desplazado: aquí la sujeto no perece eternamente, como sucede con el héroe griego, sino que es capaz de recomponerse para enfrentar de manera autosuficiente su difusión cultural, en alerta afectiva y racional de lo que ha sido la historia castrada de su pueblo y el reconocimiento de su situación actual, así como la distancia que debe franquear entre ambas. Dice:

Entonces me levanto y me rehago,
la misma cara, el mismo cuerpo
y el mismo corazón acongojado.

No es la muerte

quien me espanta a esta hora,

sino la distancia con las montañas (16).

La crisis identitaria no se resuelve por completo, sino que la sensación de desajuste y angustia que experimenta la hablante se mantiene en otro nivel. Hallando su psiquis rehabilitada - "No son los rapaces centinelas / sino el inútil deseo / del retorno a las quebradas” (16)-, revelará la urgencia del compromiso activo, y entonces, el anhelo de 
regresar a las tierras de origen y de recuperar el lugar habitado aparecen inevitables. En medio de esa pugna, que tensiona realidad y deseo, se descubre una sujeto consciente de su conflicto identitario: "Más heme aquí, cuerpo y sueño / sobre este suelo baldío" (16). Tal como nos decía Kristeva en un principio, y tal como sucedía con la constitución de la hablante poética de Sur, la “indagación retrospectiva”, que implica el cuestionamiento del ser mismo hasta su posesión, no puede resultar sino problemática.

Sin embargo, como expresa Mabel García a través de una revisión general de la escritura poética mapuche, la intertextualidad a nivel de los relatos míticos u originarios (en este caso, Kupalme y Prometeo) ha servido a modo de revisión y ampliación de ambas culturas, la de origen y la foránea, revelando la situación mestiza de escritura ${ }^{13}$. De este modo se recrean, permitiendo la recomposición identitaria en el poema y la pervivencia de la cultura marginada. Pues, en el proceso de apropiación, se ha manifestado la imagen de una sujeto fortalecida, imagen que la cultura occidental no ha sido capaz de representar en su Prometeo. Este tránsito concluirá con significativos descubrimientos en el poema final del texto, denominado "Atardecer en el río" (53), que despliega una imagen sostenida por un motivo revelador. El poema dice:

$$
\begin{aligned}
& \text { Una garza blanca } \\
& \text { desafía la tarde. } \\
& \text { Su figura inmóvil } \\
& \text { desborda el horizonte. } \\
& \text { El último rayo de luz } \\
& \text { huye sigiloso por el río. }
\end{aligned}
$$

Para la cultura mapuche, los pájaros tienen la capacidad de anunciar ciertos sucesos a través de su canto, chillido o vuelo; en este caso, la garza blanca (traiwe o kuka), símbolo de belleza, sería el ave protectora que auxilia en la noche a encontrar el camino a los extraviados (Aguas y Clavería 86) o, según otros documentos, cercanos a la misma idea, es una de las señales del perrimontun. Así lo señala Heddy Navarro en su artículo sobre la machi Hermenegilda Huentenao:

Las machis reciben el llamado de dos formas. Una, por medio del "perrimontun", que es una señal. Por ejemplo: se les atraviesa una culebra en el camino; encuentran un kultrún esperándolas en un sendero o la kuka (garza blanca) se les aparece. Son señales que un hombre o mujer mapuche no pueden ignorar. La otra forma es a través del "peuma" o sueño, en el cual son llamadas por el Chao Ngnechen (Dios Padre) a ejercer esta misión en la tierra.

13 Podemos apreciar esta misma situación en Sur, respecto de los poemas que reúnen a las divinidades católicas y las indígenas latinoamericanas. Para el caso que señalamos: la madonna Annunziata y Ometeótl (“¿Es la Primavera...?" 88). 
Esto significa que, en nuestro poema, la aparición de la garza indicaría que la reacción de enfrentamiento inicial entre las culturas que configuran su identidad ha sido resuelta por la hablante con la restitución de su filiación indígena, quien, trasladada durante el trayecto lírico al escenario natural distinguido como su lugar de origen, ha asumido su reconocimiento en el de su linaje mapuche. En este sentido, Claudia Rodríguez establece una relación analógica entre la labor de sabiduría y sanación que representa la machi, entendida como práctica intracultural, y la de las poetas mapuche actuales, destacando su posición de productoras discursivas, al rehabilitar los lazos identitarios del grupo. Sin embargo, agrega que hoy esos términos han cambiado, y que "la machi comienza a jugar un rol fundamental y a ejercer influencia política en la toma de decisiones y en las negociaciones con los winkas" (158). De manera que la relación machi-poeta también nos habla de una situación intercultural y, por tanto, de una conciencia mestiza que en la enunciación de Perrimontun privilegia el lugar mapuche. Así, la imagen poética desplegada hacia del término del poema "Atardecer en el río", compuesta por esta garza cruzando el ocaso sobre el río, como toda imagen poética concentra y despliega una serie de contenidos y sentidos que nos dan luz sobre su situación: con el augurio del ave, la tierra (che) extiende gozosa su color, trayendo consigo la presencia de la noche que tiñe la escena con los fundamentos de su identidad indígena, y que, con ese encuentro personal y comunitario, "respira hondo / para seguir viviendo" (Mora 53).

\section{Palabras finales}

Enunciados desde la urbe contemporánea, tanto Sur como Perrimontun se hacen cargo de la complejidad de las múltiples realidades que alberga el continente latinoamericano. De tal manera, producen en conjunto la liberación de conceptos como nación, identidad, etnia y género que suelen ser sometidos a la avasallante fijación y homogeneidad de la experiencia única. Esto supone una seria deuda con la diversidad tanto del mundo indígena como con la situación de las mujeres; pero, al mismo tiempo, también silencia las complejidades y resistencias de nuestra propia constitución mestiza latinoamericana, tal y como la vivimos hoy.

De esa forma, mediante la elaboración de la memoria, que expone los relatos familiares e íntimos, sociales y colectivos, ambos textos cruzan las fronteras de los discursos establecidos para reconocerse en los márgenes y desde ahí situar sujetos que, conscientes de sus conflictos identitarios, articulan diversas posiciones, dando cuenta de la hibridez de su constitución étnico-cultural y de la pluralidad de las experiencias femeninas. En este transcurso, ambos textos van hacia las sabidurías ancestrales de sus mujeres y, a partir del inventario y la revisión de sus compromisos, cargas y haberes, alumbran historias de oposiciones y relaciones culturales en las que los sujetos integrantes han debido empoderarse de la negada identidad indígena, por 
una parte, y aceptar, directa o indirectamente, con la complejidad que ello implica, la presencia del componente occidental, por otra. De tal manera, reuniendo la perspectiva de género y la diferencia étnica, marcan un discurso pensado y producido desde una doble subalternidad, la que ha debido ser reposicionada para poder hablar nuevamente de y desde una diferencia proliferante.

\section{Referencias}

Aguas Deumacán, Wilma y Clavería Pizarro, Nelson. Wera Wenu Werken. Mensajeras del cielo. Las aves en la cultura Mapuche. Osorno: Talleres Lautaro. 2009. <http:// www.mapuche.info/wps_pdf/aguas_claveria_100415.pdf>. Web. 21 Ago. 2015.

Anderson, Benedict. Comunidades imaginadas. Reflexiones sobre el origen y la difusión del nacionalismo. Buenos Aires: Fondo de Cultura Económica, 2000. Impreso.

Anzaldúa, Gloria. "La conciencia de la mestiza/ rumo a una nova consciência”. Revista de estudos feministas 13.3 (2005): 704-719. Impreso.

Baeza, Adrián. Más sabes que el blanco ciego. Pacto de lectura pedagógico con poema de Chile de Gabriela Mistral. Tesis para optar al grado de Magíster en literatura chilena e hispanoamericana, Facultad de Filosofía y Humanidades, Universidad de Chile, 2005. Impreso.

Bellesi, Diana. Sur. Buenos Aires: Libros de Tierra Firme, 1998. Impreso.

Benjamin, Walter. La dialéctica en suspenso. Fragmentos sobre la historia. Santiago: Lom, 1999. Impreso.

Chapman, Anne. Los selk’nam. La vida de los onas. Buenos Aires: Emecé, 1986. Impreso.

---. El fin de un mundo: Los selknam de Tierra del Fuego. Buenos Aires: Vázquez Mazzini, 1989. Impreso.

Cornejo Polar, Antonio. "Mestizaje e hibridez: los riesgos de las metáforas". Cuadernos de Literatura 6 (1997): 5-12. Impreso.

García, Mabel. "Entre-textos: la dimensión dialógica e intercultural del discurso poético mapuche”. Revista Chilena de Literatura 72 (2008): 29-70. Impreso.

Gissi, Nicolás. "Los mapuches en el Santiago del s. xxı: desde la ciudadanía política a la demanda por el reconocimiento". Cultura urbana. Plataforma antropología urbana. 15 Ago. 2004. Web. 21 Ago. 2015.

Jones, Rebecca. La migración por obligación. Los movimientos migratorios de los mapuche. sit Graduate Institute/sit Study Abroad. 10 Ene. 2005. <http://digitalcollections.sit.edu/cgi/viewcontent.cgi?article=1442\&context=isp_collection $>$. Web. 21 Ago. 2015.

Kristeva, Julia. La revuelta íntima. Literatura y psicoanálisis. Buenos Aires: Eudeba, 2001. Impreso.

Manquenahuel, Juan Pablo. "We Tripantu”. Recuperando la sabiduría mapuche. 2000. <http://www.galeon.com/mapunche/index.html>. Web. 21 Ago. 2015. 
---. "Valores básicos de la sabiduría ancestral". Recuperando la sabiduría mapuche. 2000. <http://www.galeon.com/mapunche/index.html>. Web. 21 Ago. 2015.

Mistral, Gabriela. Poesías Completas. Santiago: Andrés Bello, 2009. Impreso.

Montecino, Sonia. Sol Viejo, Sol Vieja. Lo femenino en las representaciones mapuche. Santiago: CEDEM, 1995. Impreso.

Mora Curriao, Maribel. Perrimontun. Inédito, 2009. Impreso.

Navarro, Heddy. "Hermenegilda Huentelao: Machi de Temu Lemu”. Ser indígena. 16 Ene. 2006). <http://www.revista.serindigena.org/?p=74>. Web. 21 Ago. 2015.

Pinto, Karem. "Nombrar el margen: etnia y género en Sur de Diana Bellesi”. Caminos y desvios. Lecturas críticas sobre género y escritura en América Latina. Eds. Alicia Salomone, Lorena Amaro y Ángela Pérez. Santiago de Chile: Cuarto Propio, 2010. 107-128. Impreso.

Pratt, Mary Louise. "Las mujeres y el imaginario nacional en el siglo xix". Revista de Crítica Literaria Latinoamericana 38 (1993): 51-62. Impreso.

Rodríguez, Claudia. "Weupüfes y machis: canon, género y escritura en la poesía mapuche actual”. Estudios Filológicos 40 (2005): 151-163. Impreso.

Rojo, Grínor. Dirán que está en la gloria... (Mistral). Santiago: Fondo de Cultura Económica, 1997. Impreso.

Recibido: 20 agosto 2014

Aceptado: 06 agosto 2015 